\title{
Analisis Kinerja PDAM Kota Padang Panjang dalam memberikan Pelayanan Air Bersih untuk Masyarakat Kota Padang Panjang
}

\section{Citra Dwi Putri, Kusdarini, Roni Ekha Putera}

Jurusan Administrasi Publik, Universitas Andalas, Indonesia.

\begin{tabular}{|c|c|}
\hline ARTICLE INFORMATION & $\mathrm{A} B \mathrm{~S} \mathrm{~T} \mathrm{R}$ A C $\mathrm{T}$ \\
\hline Received: January 27, 2021 & \multirow{8}{*}{$\begin{array}{l}\text { This research is motivated by the large number of water resources owned by PDAM Padang Panjang city. } \\
\text { Furthermore, PDAM Padang Panjang city also has a breakthrough in activities that are not owned by other } \\
\text { PDAMs in the West Sumatra region. Nevertheless, in reality, PDAM Padang Panjang City has not provided } \\
\text { the same service to all its service areas. The research objective is to describe the performance of PDAM Padang } \\
\text { Panjang in providing clean water for the people of Padang Panjang City. The research method used in this } \\
\text { research is descriptive qualitative with data collection techniques using interviews, observation, and } \\
\text { documentation. To test the validity of the data obtained, it was carried out through source triangulation } \\
\text { techniques. The theory used in this research is the theory of performance, according to Wibowo, which consists } \\
\text { of four variables, namely input, process, output, and benefits. The results showed that from the four variables } \\
\text { put forward by Wibowo, it could be concluded that the performance of PDAM Padang Panjang in providing } \\
\text { clean water for the people of Padang Panjang has not been maximally achieved. Because there are still several } \\
\text { indicators from the theory used that have not achieved the results expected by the PDAM. For example, the } \\
\text { human resources in the PDAM have not received evenly distributed training, incomplete financial } \\
\text { management, incomplete supporting documents, and the management of existing natural water sources has not } \\
\text { been maximized. }\end{array}$} \\
\hline Revised: February 16, 2021 & \\
\hline Accepted: April 14, 2021 & \\
\hline Available online: April 17, 2021 & \\
\hline KEYWORDS & \\
\hline Performance, PDAM, and Clean Water & \\
\hline CORRESPONDENCE & \\
\hline $\begin{array}{l}\text { Phone: +6281363253093 } \\
\text { E-mail: roniekhaputera@soc.unand.ac.id }\end{array}$ & \\
\hline
\end{tabular}

\section{PENDAHULUAN}

Air bersih merupakan kebutuhan semua masyarakat, dalam pengelolaan serta pendistribusian air bersih di Indonesia dikelola oleh negara. Perusahaan Daerah Air Minum (PDAM) merupakan perusahaan yang diberi wewenang oleh negara dalam mengelola sumber daya air dan pemanfaatannya yang bisa dikonsumsi oleh masyarakat umum. Menurut Arindha Ayu (2010), PDAM masuk dalam kategori penyelenggara pelayanan yang bersifat profit dengan tugasnya memberikan pelayanan air bersih kepada warga masyarakat pada suatu daerah. PDAM sebagai salah satu instansi pemerintah yang berbentuk BUMD memiliki jenis pelayanan yang termasuk dalam kelompok pelayanan barang yaitu pelayanan yang menghasilkan berbagai bentuk/jenis barang dalam hal ini adalah penyediaan air bersih.

Peran yang penting yang diemban oleh Perusahaan Daerah Air Minum (PDAM) sebagai penyelenggara jasa keairan utama di Indonesia adalah untuk menjaga agar pelanggan menjadi loyal, maka dengan demikian kepuasan pelanggan menjadi prioritas. Perusahaan Daerah Air Minum (PDAM) berusaha memuaskan pelanggan perusahaan dengan memberikan pelayanan yang lebih baik. Sebagai perusahaan yang mengacu pada customer focus, maka Perusahaan Daerah Air Minum tersebut tidak bisa membiarkan terjadinya complain atau keluhan yang diajukan pelanggannya. Adapun Keluhan yang disampaikan oleh pelanggan tersebut adalah salah satu dari wujud tanggung jawab sosial yang dilakukan oleh Perusahaan Daerah Air Minum (PDAM), dengan maksud bahwa PDAM mempunyai kewajiban dalam memberikan pelayanan kepada seluruh lapisan masyarakat tanpa memandang status sosialnya.
Selain itu, juga dituntut bahwa dalam pengelolaannya agar menganut prinsip-prinsip ekonomi yaitu memperoleh keuntungan (profit oriented) guna menunjang kelangsungan hidup dan pelayanan serta perluasan area pelayanan. Keluhankeluhan yang diajukan biasanya berkisar pada masalah teknis, yaitu: air mengalir tidak bersih dan kotor (agak keruh), air mati, kerusakan pipa, kebocoran saluran pipa yang mengakibatkan tagihan air membengkak, kesalahan pada pencatatan meteran.

Pentingnya persoalan kebutuhan air bagi masyarakat ini, seperti kebutuhan papan, pangan, dan sandang, seyogyanya pemerintah harus memberikan perhatian khusus dalam masalah pengelolaan air, baik dari segi penambahan dan pengurangan pipa PDAM agar tidak mengurangi debit air untuk irigasi persawahan. Menurut Kusnaedi (2010) Pengelolaan air bersih merupakan upaya untuk mendapatkan air yang bersih dan sehat sesuai dengan standar mutu air untuk kesehatan. Proses pengolahan air minum merupakan proses perubahan sifat fisik, kimia, dan biologi air baku agar memenuhi syarat untuk digunakan sebagai air minum. Tujuan dari sistem penyediaan air bersih adalah menyediakan jumlah air yang cukup untuk kebutuhan masyarakat sesuai dengan tingkat kemajuan dan perkembangan daerah pelayanan.

Sebagai peningkatan pelayanan air minum kepada masyarakat sesuai dengan amanat Peraturan Pemerintah No 122 Tahun 2015 tentang Sistem Penyediaan Air Minum (SPAM), maka PDAM wajib memenuhi unsur 3K (kualitas, kuantitas dan kontinuitas) guna memberikan pelayanan kepada masyarakat. Oleh karena itu, usaha untuk memberikan pelayanan air bersih bagi masyarakat Kota Padang Panjang 
yang mengalami pertumbuhan dan perkembangan yang semakin meningkat, PDAM dituntut untuk dapat mengantisipasi kondisi tersebut.

Berikut pada tabel 1. merupakan sumber air yang digunakan oleh masyrakat Kota Padang Panjang untuk memenuhi kebutuhan air:

Tabel 1. Sumber Air Bersih Yang Digunakan

\begin{tabular}{lll}
\hline No & Deskripsi & $\%$ \\
\hline 1 & Air PDAM & 46.67 \\
2 & Sumur & 2.00 \\
3 & Sungai & 25.33 \\
4 & Kolam & 8.00 \\
5 & Mata air & 8.00 \\
6 & Beli air & 10.00 \\
\hline & Jumlah & 100.00 \\
\hline
\end{tabular}

Sumber: dokumen business plan hal 101

Sebagian besar masyarakat Kota Padang Panjang memanfaatkan air bersih dari PDAM, namun sebenarnya masih ada sumber air lain yang dapat digunakan oleh masyarakat untuk memperoleh air bersih tanpa melalui jasa PDAM kota. Jal ini dikarena masyarakat memiliki alasan tersendiri untuk memilih sumber air apa yang akan mereka manfaatkan. Seperti menggunakan sumur sendiri karena tidak memiliki uang untuk membayar jasa PDAM, ada juga yang masih menggunakan air dari sungai yang ada disekitar rumah mereka.

Untuk menunjang kinerja PDAM dalam penyediaan air bersih kepada masyarakat Kota Padang Panjang, dibutuhkan masukan berupa sumber daya manusia dan juga sumber daya lainnya. Berikut pada tabel 2. merupakan daftar sumber daya manusia yang dimiliki oleh PDAM Kota Padang Panjang:

Tabel 2. Daftar Jumlah Pegawai PDAM Kota Padang Panjang

\begin{tabular}{llr}
\hline No. & Bagian & Jumlah (orang) \\
\hline 1 & Perencanaan & 3 \\
2 & Produksi & 11 \\
3 & Distribusi & 9 \\
4 & Kepala Administrasi dan & 1 \\
& Keuangan & \\
5 & Umum & 11 \\
6 & Keuangan & 3 \\
7 & Langganan & 12 \\
8. & Kepala Bagian Teknik & 1 \\
\hline & $\quad$ Jumlah & 51 \\
\hline
\end{tabular}

Sumber: dokumen Proyeksi Kebutuhan PDAM Kota Padang Panjang

Selain SDM, yang menjadi input kinerja pada PDAM Kota Padang Panjang dalam penyediaan air bersih adalah anggaran, karena anggaran merupakan suatu sumber daya yang sangat mempengaruhi tercapainya sebuah tujuan. Sumber anggaran yang dipergunakan dalam memberikan pelayanan berupa air bersih kepada masyarakat Kota Padang Panjang bersumber dari sumber APBN, APBD Kota dan PDAM. Berikut pada tabel 3 rincian sumber dana masing-masing tahun anggaran:

Tabel 3. Pembiayaan Program Gabungan PDAM Kota Padang Panjang Tahun 2015-2019.

\begin{tabular}{lrrrrrr}
\hline Sumber & \multicolumn{3}{c}{ Tahun $(\mathrm{Rp} \times 1.000 .000)$} & \multicolumn{1}{c}{ Jumlah (Rp } \\
Dana & 2015 & 2016 & 2017 & 2018 & 2019 & $\mathrm{x} 1.000 .000)$ \\
\hline PDAM & 503 & 3.001 & 1.812 & 1.802 & 2.021 & 9.139 \\
APBD & 3.229 & 2.025 & 3.383 & 4.404 & 9.607 & 22.646 \\
APBN & 1.800 & - & - & - & 6.495 & 8.295 \\
\hline Jumlah & 5.532 & 5.026 & 5.195 & 6.206 & 18.123 & 40.081
\end{tabular}

Sumber : dokumen business plan hal 239

Anggaran yang diperoleh dari sumber APBN, APBD Kota dan PDAM tersebut dimanfaatkan untuk menunjang kinerja PDAM dalam memberikan air bersih kepada masyarakat Kota Padang Panjang.

Untuk dapat memproses semua sumber daya yang telah dimiliki oleh PDAM Kota Padang Panjang, PDAM memiliki sebuah dokumen yang berisi perencanaan serta target yang harus dicapai oleh PDAM dalam jangka waktu lima tahun. Dokumen tersebut adalah dokumen Business Plan yang telah disiapkan oleh perusahaan yang mendeskripsikan semua unsur yang relevan baik internal maupun eksternal mengenai perusahaan untuk memulai pada waktu usaha. Berikut ini merupakan tujuan sistem penyediaan air bersih sampai tahun 2019 terdiri atas:

1. Peningkatan tingkat pelayanan dengan target tahun 2019 yaitu $85 \%$ penduduk terlayani

2. Rehabilitasi atau perbaikan kondisi

3. Meningkatkan tingkat dan kualitas pelayanan

4. Menurunkan tingkat kehilangan air

Dari tujuan sistem penyediaan air bersih di atas, PDAM menurunkannya menjadi kegiatan yang akan memudahkan PDAM dalam pencapaian tujuannya. Kegiatan tersebut adalah, ZAMP, DMA, dan juga Pelayanan Pengaduan. Pada kegiatan pelayanan pengaduan, pelanggan PDAM bisa langsung menghubungi PDAM untuk menyampaikan keluhan yang dirasakan kepada PDAM. Berikut pada tabel 4. merupakan tabel capaian pelayanan PDAM Kota Padang Panjang:

Tabel 4. Tabel Capaian Pelayanan Air Bersih PDAM Kota Padang Panjang

\begin{tabular}{|c|c|c|c|c|c|}
\hline \multirow{2}{*}{ Uraian } & \multirow{2}{*}{ Satuan } & \multicolumn{4}{|c|}{ Tahun } \\
\hline & & 2016 & 2017 & 2018 & 2019 \\
\hline Jumlah & Jiwa & 50.361 & 51.162 & 51.975 & 52.994 \\
\hline Penduduk & & & & & \\
\hline Penduduk & Jiwa & 45.324 & 47.424 & 49.524 & 39.992 \\
\hline Terlayani & & & & & \\
\hline Penduduk & $\%$ & 89,99 & 92,7 & 95,3 & 75,47 \\
\hline Terlayani & & & & & \\
\hline
\end{tabular}

Sumber: Olahan Peneliti tahun 2020

Dari perbandingan data ini, peneliti berasumsi ada faktor lain yang mempengaruhi kinerja PDAM sehingga tidak dapat mencapai target dari tujuan yang telah ditetapkan.

Organisasi dibentuk untuk dapat mencapai tujuan yang telah ditetapkan. Kinerja merujuk kepada keberhasilan suatu kegiatan atau program yang dilakukan oleh organisasi dalam mencapai tujuan yang telah ditetapkan. bahwa penilaian kinerja organisasi dapat digunakan sebagai ukuran keberhasilan suatu organisasi dalam kurun waktu tertentu dan penilai tersebut juga dapat dijadikan input bagi perbaikan dan peningkatan kinerja organisasi (Ariany dan Putera, 2013). Dalam hal ini jika dilihat dari fenomena-fenomena yang telah dijelaskan oleh peneliti di atas, peneliti tertarik untuk mengaitkan bagaimana kinerja PDAM dalam penyediaan air 
bersih bagi masyarakat Kota Padang Panjang dengan menggunakan teori kinerja menurut Wibowo. Karena peneliti berasumsi kinerja PDAM masih belum optimal sehingga belum semua masyarakat Kota Padang Panjang bisa memperoleh air bersih dari PDAM. Dengan begitu peneliti memilih menggunakan teori kinerja karena dengan teori ini dapat membantu peneliti untuk melihat bagaimana kinerja PDAM pada tahapan input, process, output dan benefit dalam penyediaan air bersih bagi masyarakat Kota Padang Panjang

Berdasarkan ulasan yang telah dijelaskan sebelumnya maka yang menjadi rumusan masalah adalah "Bagaimana Analisis Kinerja PDAM dalam memberikan Penyediaan Air Bersih untuk Masyarakat Kota Padang Panjang?"

\section{METODE}

Penelitian ini menggunakan pendekatan kualitatif dengan metode deskriptif, pengumpulan data dilakukan melalui proses wawancara, dokumentasi, dan observasi. Wawancara yang dilakukan menggunakan Teknik wawancara tidak terstruktur. Informan dipilih dengan teknik purposive sampling, terdapat beberapa orang informan yang peneliti wawancarai diantaranya; 1) Wali Kota Padang Panjang, 2) Sekretaris Daerah), 3) Direktur. PDAM Kota Padang Panjang, 4) Kasubag Perencanaan Setda Kota Padang Panjang, 5) Kasubag Umum Setda. Kota Padang Panjang), 6) Staf Bagian Distribusi), 7) Staf Bagian Umum, 8) Staf Bagian Perencanaan). Pengumpulan data dengan dokumentasi dilakukan dengan menganalisa data yang diperoleh dari dokumen-dokumen yang terkait dengan penelitian seperti yang digunakan dalam penelitian ini berupa peraturan-peraturan, surat keputusan, laporan tahunan, arsip, dan juga dokumen bussines plan yang dimiliki oleh PDAM Kota Padang Panjang. Unit analisis dalam penelitian ini adalah lembaga, yakni PDAM Kota Padang Panjang. Sedangkan untuk triangulasi data dari hasil temuan penelitian ini adalah masyarakat yang menjadi sasaran PDAM Kota Padang Panjang.

\section{HASIL DAN PEMBAHASAN}

Adapun yang menjadi bahasan dalam penelitian ini adalah ada beberapa variabel yang dilihat, untuk dapat mengetahui kinerja PDAM Kota Padang Panjang dalam penyedaian air bersih bagi masyarakat Kota Padang Panjang. Pengukuran kinerja sektor publik menurut Wibowo meliputi: (1) masukan (input), (2) proses (process), (3) keluaran (output), (4) manfaat.

Air bersih adalah kebutuhan manusia yang paling mendasar dan sangat diperlukan untuk mendukung berbagai kegiatan perekonomian. Kebutuhan terhadap air bersih yang terolah utamanya di daerah perkotaan akan selalu ada dan meningkat dari waktu ke waktu mengikuti peningkatan jumlah dan kepadatan penduduk, peningkatan perekonomian serta transformasi social dan cultural di masyarakat. Dalam hal ini, PDAM harus memiliki peran besar untuk dapat menyediakan air bersih yang sesuai dengan ketentuan untuk masyarakat setempat.

Pertama variabel masukan (input) memiliki dua indikator yakni adanya sumber daya manusia dan juga sumber daya lainnya. Dalam manajemen kinerja, berbagai ragam masukan harus dapat dikelola secara sinergi. Dapat dilihat pada variable masukan, setiap indikator terlihat belum bersinergi dengan baik seperti yang dimaksudkan oleh teori. Terlihat dari belum semuanya mendapatkan pelatihan untuk meningkatkan pengetahuan dan kemampuannya karena terhalang oleh dana yang dimiliki oleh PDAM, sehingga dalam mengelola sumber daya lainnya yang dimiliki oleh PDAM belum optimal. Dan pada sumber daya lainnya, PDAM belum bisa mengoptimalkan sumber air baku yang ia miliki untuk dapat memberikan pelayanan air bersih kepada masyarakat, padahal PDAM memiliki lumayan banyak sumber air baku.

Variabel kedua adalah proses, pada variabel ini terdapat empat indikator yakni perencanaan tujuan, pelaksanaan kegiatan, monitoring, dan juga pengukuran kinerja.

Tujuan merupakan apa yang diharapkan untuk dicapai oleh sebuah organisasi dalam suatu periode waktu tertentu. Dalam penelitian ini, peneliti menyimpulkan bahwa PDAM Kota Padang Panjang sudah menyiapkan rancangan program kerja yang akan dijalankan guna tercapainya tujuan PDAM. Dengan tercapainya semua rancangan program kerja PDAM, maka PDAM akan bisa memberikan pelayanan air bersih kepada masyarakat Kota Padang Panjang.

Dalam pelaksanaan kegiatan, PDAM Kota Padang Panjang memiliki program yang tidak dimiliki oleh PDAM lain di Sumatera Barat, yakni adanya program ZAMP, DMA, dan juga Layanan Pengaduan. Program ZAMP (Zona Air Minum Prima) merupakan program dari pusat yang dirancang oleh BPPSPAM (Badan Peningkatan Penyelenggaraan Sistem Penyedian Air Minum), yakninya melakukan pendampingan khusus kepada daerah pelayanan kepada daerah layanan, upaya ini guna memberikan pelayanan kebutuhan air minum bagi masyarakat, adanya kerjasama yang dijalin oleh PERPAMSI (Persatuan Perusahaan air Minum Seluruh Indonesia) dengan USAID untuk membantu PDAM seluruh Indonesia. Program DMA (District Area Meter) merupakan wilayah yang terisolasi baik permanen maupun non permanen yang dilengkapi dengan instrument pembentuk DMA seperti water meter district (meter air induk DMA) dan katup batas DMA serta instrument control DMA. DMA ini dirancang untuk mengurangi resiko kebocoran air pada pipa PDAM. Sedangkan Layanan Pengaduan merupakan program khusus yang dirancang oleh PEMDA Kota Padang Panjang untuk mempermudah masyarakat dalam menangani setiap masalah yang dilami, tidak hanya pelayanan PDAM, tetapi juga termasuk pelayanan kesehatan, dan pelayanan keamanan. Layanan pengaduan ini bisa dilakukan di media social seperti SMS, Facebook, Instagram, dan menghubungi panggilan darurat 112. Jika dikaitkan dengan indikator pelaksanaan kegiatan yang dikemukakan oleh Wibowo, terlihat bahwa PDAM masih belum melakukan perencanaan dan tujuan yang jelas dalam setiap kegiatan. Terutama pada kegiatan ZAMP dan juga kegiatan DMA. Karena terlihat bahwa PDAM tidak siap untuk menjalankan kegiatan tersebut, mulai dari tidak adanya perencanaan yang jelas terkait dengan kegiatan, hingga tidak adanya bagian khusus yang menangani kegiatan tersebut. Sehingga yang dilakukan PDAM dalam kegiatan untuk penyediaan air bersih untuk masyarakat masih belum maksimal.

Monitoring dilakukan guna mengetahui secara lebih dini apabila terjadi penyimpangan dari perencanaan sebuah kegiatan. Dalam hal ini PDAM Kota Padang Panjang sudah melakukan pengawasan atau monitoring secara langsung pada waktu yang telah ditetapkan saja. Biasanya monitoring ini dilakukan 1 kali setiap bulan, akan tetapi selalu menyesuaikan dengan kondisi yang ada dilapangan. Sehingga jika terjadi kesalahan ditengah sebuah pekerjaan, PDAM belum bisa 
menanganinya secara cepat. Padahal menurut teori, monitoring dilakukan untuk mengetahui kesalahan dini dan menanggulanginya secara cepat dan tanggap.

Variabel proses yang dikemukakan oleh Wibowo belum berjalan dengan cukup baik. Dapat dilihat dari setiap indikatornya PDAM Kota Padang Panjang tidak menjabarkan dengan rinci sehingga tidak semua aspek bisa dilihat bagaimana prosesnya. Tidak hanya itu, PDAM hanya memiliki sedikit dokumen tertulis dalam menjalankan setiap kegiatannya. Sehingga sangat susah untuk dilihat bagaimana sebenarnya PDAM melakukan suatu kegiatan atau program yang menunjang pelayanan air bersih untuk masyarakat. Variabel proses merupakan bagaimana kinerja itu dilakukan, sehingga pada tahapan proses dapat memperbaiki lebih awal semua kesalahan yang terjadi. Dengan demikian akan mempermudah dalam pencapaian tujuan PDAM dan memberikan pelayanan air bersih kepada masyarakat tidak terganggu.

Selanjutnya variabel keluaran yang memiliki satu indikator yakni hasil kerja. pada variabel keluaran (output) dan indikator hasil kerja, bahwa keluaran dari kinerja PDAM dalam upaya pemberian pelayanan air bersih kepada masyarakat Kota Padang Panjang menurut teori Wibowo belum optimal. Untuk lebih jelas, berikut disajikan data pada tabel 5. empat tujuan yang telah dirancang oleh PDAM Kota Padang Panjang.

Tabel 5. Empat tujuan yang dirancang oleh PDAM Kota Padang Panjang

\begin{tabular}{llll}
\hline No & Tujuan & Keterangan \\
\hline 1. & $\begin{array}{l}\text { Peningkatan tingkat pelayanan } \\
\text { dengan target tahun 2019 }\end{array}$ & Belum mencapai \\
target & \\
sebanyak $85 \%$ penduduk & \\
terlayani & $\begin{array}{l}\text { Rehabilitasi atau perbaikan } \\
\text { kondisi }\end{array}$ & Terlaksana \\
3. $\quad \begin{array}{l}\text { Meningkatkan tingkat dan } \\
\text { kualitas pelayanan }\end{array}$ & Terlaksana \\
4. & $\begin{array}{l}\text { Menurukan tingkat kehilangan } \\
\text { air }\end{array}$ & Terlaksana \\
\end{tabular}

Sumber: Diolah oleh peneliti tahun 2020

Tujuan pertama yakni peningkatan tingkat pelayanan dengan target tahun 2019 yaitu 85\% penduduk terlayani. PDAM belum bisa mencapai target yang ia tetapkan untuk tahun 2019. Tapi tiga dari empat tujuan yang dirancang oleh PDAM berhasil tercapai pada tahun 2019 yakninya rehabilitasi atau perbaikan kondisi, meningkatkan tingkat dan kualitas pelayanan dan menurunkan tingkat kehilangan air. Menurut hasil kerja yang dapat dicapai oleh sebuah organisasi perlu dibandingkan dengan tujuan yang diharapkan oleh sebuah organisasi. Walaupun kegiatan yang dirancang oleh PDAM untuk memberikan pelayanan air bersih kepada masyarakat tidak terlalu membantu dalam mencapai tujuan yang telah dirancang oleh PDAM Kota Padang Panjang.

Variabel terakhir adalah variabel manfaat, pada variabel manfaat yang dikemukakan oleh Wibowo untuk mengetahui kinerja sebuah organisasi publik ini, sudah sejalan dengan apa yang terjadi dilapangan terkait dengan manfaat apa yang dirasakan. Secara garis besar, PDAM telah berhasil memberikan manfaat yang berdampak positif kepada sebagian besar masyarakat yang menjadi pelanggan PDAM Kota Padang Panjang. Tapi masih ada beberapa masyarakat yang belum bisa menikmati air dari saluran PDAM karena terkendala dengan dana atau biaya masuk awal yang dianggap lumayan mahal oleh sebagian kecil masyarakat Kota Padang Panjang. Dan terkait dengan kegiatan yang dilakukan oleh PDAM Kota Padang Panjang dalam penyedaiaan air bersih bagi masyarakat Kota Padang Panjang masih belum optimal, karena kegiatan ZAMP dan DMA perlu ditinjau ulang apa perannya dalam meningkatkan kinerja PDAM dan mencapai tujuan PDAM Kota Padang Panjang.

Dari beberapa variabel yang dikemukakan dalam hasil penelitian ini, terlihat bahwa belum maksimalnya kinerja PDAM Kota Padang Panjang dalam penyedian air bersih bagi masyarakat Kota Padang Panjang. Seperti yang telah peneliti jelaskan sebelumnya bahwa kendala ini disebabkan oleh beberapa indikator yakni kapabilitas sumber daya manusia yang belum merata, sumber air yang dimiliki oleh PDAM belum memenuhi syarat dan ketentuan Kemenkes. Jika dilihat dari program kerja yang dirancang dan dimiliki oleh PDAM, belum semua diketahui oleh masyarakat, serta monitoring yang tidak sesuai dengan rencana dan waktu yang ditetapkan juga menjadi factor yang mempengaruhi, akan tetapi dari manfaat layanan pengaduan yang di programkan dapat memberikan pelayanan yang cepat dan tanggap kepada masyarakat, ini yang menekan angka kehilangan air oleh PDAM

\section{KESIMPULAN}

Dalam usaha untuk memberikan pelayanan air bersih bagi masyarakat Kota Padang Panjang yang mengalami pertumbuhan dan perkembangan yang semakin meningkat, PDAM dituntut untuk dapat mengantisipasi kondisi tersebut. Namun disadari bahwa kapasitas sumber daya, kemampuan sistem dan kapasitas produksi yang tersedia masih terbatas dan perlu terus ditingkatkan, untuk itu PDAM harus dikelola dengan sistem manajemen yang baik dan profesional agar dapat secara terus menerus memenuhi kebutuhan air bagi masyarakat. Sebagai salah satu unit usaha yang melayani kebutuhan manusia yang sangat mendasar yaitu air bersih, PDAM Kota Padang Panjang perlu meningkatkan kinerjanya dari waktu ke waktu mengikuti pertambahan penduduk dan peningkatan taraf hidup masyarakat di daerahnya.

Secara keseluruhan kinerja PDAM Kota Padang Panjang belum maksimal, karena belum semua tujuan yang direncanakan di awal bisa tercapai dengan baik oleh PDAM. Selain itu peneliti melihat belum semua sumber daya manusia atau pegawai PDAM menerima pendidikan dan pelatihan untuk meningkatkan kapabilitasnya. Dalam pengelolaan sumber air baku PDAM juga dinilai cukup baik dalam pengelolaan, karena didukung oleh kualitas air dari sumber air memang sudah bersih sehingga pihak PDAM tidak perlu terlalu melakukan pengolahan. Tapi pada situasi tertentu seperti hujan lebat atau bahkan kemarau, PDAM belum mendapatkan jalan keluar untuk masalah kekeringan ataupun air yang keruh.

Dilihat dari proses penyediaan air bersih untuk masyarakat, PDAM memiliki tujuan yang telah ditetapkan, dan mengajarkannya dalam bentuk program kerja. Dari program kerja tersebut PDAM membuat suatu gebrakan yang hanya dimiliki oleh PDAM Kota Padang Panjang yakni berupa ZAMP, DMA, dan Layanan Pengaduan. Dalam pelaksanaan kegiatannya, PDAM dinilai kurang serius oleh peneliti karena pada tiga kegiatan menjadi pembeda PDAM Kota Padang Panjang dengan PDAM lain tersebut tidak memiliki dokumen pendukung dalam pelaksanaannya. Dokumen yang peneliti 
maksud adalah seperti dokumen petunjuk teknis, petunjuk pelaksanaan, atau bahkan laporan terkait kegiatan tersebut. Sehingga dalam mengukur kinerja PDAM terkait kegiatan tersebut menjadi sedikit sulit. Monitoring yang dilakukan oleh PDAM dalam mengawasi kinerja pegawainya dilakukan sesuai dengan kegiatan atau pekerjaan seperti apa yang akan diawasi. Biasanya, masing-masing bidang yang melakukan pengawasan kepada stafnya, selanjutnya kasubag yang melaporkan kepada Direktur selaku atasan PDAM. Terkadang Direktur langsung melihat kelapangan bagaimana kinerja para pegawainya. Karena monitoring dilakukan secara terjadwal, jadi dalam menjalankan pekerjaan atau tugasnya, pegawai PDAM lalai dalam memperhatikan kesalahan-kesalahan kecil yang bisa menghambat pencapaian tujuan PDAM. Pengukuran kinerja pegawai maupun PDAM secara keseluruhan dilakukan sekali setahun dengan memperhatikan empat aspek, yakni aspek keuangan, aspek pelayanan, aspek operasional, dan aspek SDM.

Dilihat dari variabel manfaat, PDAM Kota Padang Panjang secara umum sudah memberikan manfaat yang positif kepada pelanggannya. Selain itu dengan banyaknya masyarakat Kota Padang Panjang yang menjadi pelanggan PDAM, pihak PDAM juga mendapatkan keuntungan. Tapi peneliti menemukan kasus lain saat turun lapangan yakni masih ada masyarakat Kota Padang Panjang yang belum menjadi pelanggan PDAM karena terkendala biaya masuk pertama yang dinilai mahal. Selain itu kegiatan yang dibuat untuk mempermudah pencapaian tujuan tidak banyak mengambil peran dalam pencapaian tujuan PDAM. Tapi jika dilihat secara keseluruhan, PDAM bisa mencapai 3 tujuan dari 4 tujuan yang dirancang sebelumnya. Kinerja PDAM dalam mencapai tujuan dinilai masih belum maksimal karena belum semua tujuan PDAM dapat tercapai pada tahun 2019.

\section{REFERENSI}

Ariany, R., \& Putera, R. (2013). Analisis Kinerja Organisasi Pemerintah dalam Memberikan Pelayanan Publik di Kota Pariaman. MIMBAR : Jurnal Sosial dan Pembangunan, 29(1), 33-40. doi:https://doi.org/10.29313/mimbar.v29il.364

Data Pegawai PDAM Kota Padang Panjang Tahun 2019

Data Pegawai Penerima DIKLAT tahun 2019

Dokumen Business Plan PDAM Kota Padang Panjang tahun 20152019

Dokumen Evaluasi Kinerja PDAM Kota Padang Panjang Tahun 2016

Dokumen Evaluasi Kinerja PDAM Kota Padang Panjang Tahun 2019

Dokumen Laporan Umum PDAM

Dokumen RKAP (Rencana Kerja dan Anggaran Perusahaan) tahun 2020

Dokumen Program Kerja PDAM Tahun 2019

Dokumen Rencana Induk Pengembangan Sistem Penyediaan Air Minum Kota Padang Panjang Tahun 2016-2036

Dokumen Pengaduan Pelanggan PDAM Tahun 2019

Fahmi, I. (2016). Pengantar Manajemen Sumber Daya Manusia. Jakarta: Mitra Wacana Media.

Formulir Permohonan Menjadi Pelanggan PDAM Kota Padang Panjang

Hafizhah. (2020). Dalam Pemanfaatan Dan Pemeliharaan Hasil Program. Jurnal Administrasi Publik Dan Pembangunan, 2(1), 1521.
Keban, Y. T. (2008). Enam Dimensi Strategi Administrasi Publik. Yogyakarta: Gava Media.

Khairani, F. (2009). Kinerja Perusahaan Daerah Air Minum (PDAM) Kota Padang Dalam Upaya Peningkatan Pelayanan Publik. Padang: Universitas Andalas. Skripsi. Tidak dipublikasikan

Mahmudi. (2010). Manajemen Kinerja Sektor Publik. Yogyakarta: Sekolah Tinggi Ilmu Manajemen.

Mahmudi. (2015). Manajemen Kinerja Sektor Publik . Yogyakarta: Sekolah Tinggi Ilmu Manajemen .

Mahsun. (2009). Pengukuran Kinerja Sektor Publik. Yogyakarta: Bpfe-Yogyakarta.

Moleong. (2002). Metode Penelitian Kualitatif. Bandung: Pt. Remaja Rosdakarya.

Natalia, B. (2014). Implementasi Program Zona Air Minum Prima (ZAMP) Untuk Memenuhi Kebutuhan Air Minum Masyarakat (Studi Pada PDAM Kota Malang). Jurnal Administrasi Publik Mahasiswa Universitas Brawijaya, 2(1), 11-15.

Pasolong, H. (2007). Teori Administrasi Negara. Bandung: Alfabeta.

Peraturan Pemerintah No 122 Tahun 2015 tentang Sistem Penyediaan Air Minum (SPAM)

Pu.go.id (2019). BPPSPAM Dampingi PDAM Padang Panjang Terapkan Zamp. Diakses di https:/www.pu.go.id/berita/view/15178/bppspam-

dampingi-pdam-padang-panjang-terapkan-zamp （pada tanggal 10 september 2019)

Peraturan Menteri Kesehatan Republik Indonesia No. 492/MENKES/PER/IV/2010 tentang Persyaratan Kualitas Air Minum

Sudarmanto. (2009). Kinerja Dan Pengembangan Kompensasi Sdm. Yogyakarta: Pustaka Pelajar.

Sugiono. (2016). Metode Penelitian Kuantitatif, Kualitatif, Dan ReDD. Bandung: Alfabeta.

Wibowo. (2007). Manajemen Kinerja. Jakarta: Pt. Raja Grafindo Persada.

Wibowo. (2017). Manajemen Kinerja Edisi Kelima. Depok: Pt. Rajagrafindo Persada. 